\title{
Tespit Edici İşlemlerle Bağlantılı Olarak İdari Yargılama Hukukunda Tespit Davalarının Uygulama Alanı ve Gerekliliği Üzerine Bir Değerlendirme
}

\author{
An Evaluation on the Purview and Necessity of Declaratory Cases in \\ Administrative Procedure Law Connection with Declaratory Acts
}

\author{
Onur KAPLAN ${ }^{* *}$ iD \\ Gül Fiş ÜSTÜNN** (D)
}

Öz

İdarenin kamu gücü ayrıcalıklarından yararlanarak tesis ettiği idari işlemlerin hukuk düzeninde etki ve sonuç doğurabilmesi karşısında, bireylerin temel hak ve hürriyetlerinin korunmasında en etkin yol yargısal başvuru olarak karşımıza çıkmaktadır. Bununla birlikte idari yargılama hukukunda dava türlerinin belirli formlarla ifade edilen sinırlı bir yapıda bulunduğu göz önüne alındığında; bu durumun bireylerin etkin bir yargısal yoldan yararlanamaması neticesine yol açacağı da ifade edilebilecektir. Özellikle idari işlemlerin çeşitli konulara yönelmesi ve hukuka uygunluk karinesinden yararlanması karşısında belirli hukuki konuların yargısal yola başvurularak saptanmasında bireylerin hukuki menfaatlerinin bulunduğundan bahsedilebilir. $\mathrm{Bu}$ anlamda kamu hukukunu ilgilendiren uyuşmazlıkların idari yargı düzeninde çözümlenmesi gereğine rağmen, idari yargılama hukukunda delil tespiti kurumunun sadece maddi olguların tespitine yönelmesi ve dava türlerinin sınırlı sayıda olduğu görüşü karşısında, söz konusu hukuki menfaatin tam olarak karşılanmasına yönelik herhangi bir hukuki müessesenin bulunmadığı belirtilebilir. $\mathrm{Bu}$ doğrultuda, çalışmada öncelikle tespit davası kavramı tanımlanarak uygulama alanı belirtilecek; sonrasında tespit davalarının idari yargılama hukukunda gerekliliği meselesi irdelenecektir.

Anahtar Kelimeler: İdari İşlem, İdari Dava, Tespit Davası, Delil Tespiti, Hukuki Menfaat.

\section{Abstract}

Judicial application is the most effective way to protect the fundamental rights and freedoms of individuals in the face of the administrative acts established by the administration by taking advantage of the privileges of the public power and which may have an effect and result in the legal order. However, considering that the types of cases in administrative procedure law have a limited structure expressed

* Bu çalışma, “İdare Hukukunda Tespit Edici İşlemler” isimli doktora tezinden türetilmiştir.

** Arş. Gör., İstanbul Bilgi Üniversitesi Hukuk Fakültesi İdare Hukuku Anabilim Dalı, E-Mail: onur.kaplan@bilgi.edu.tr

*** Prof. Dr., Marmara Üniversitesi Hukuk Fakültesi İdare Hukuku Anabilim Dall, gul.ustun@marmara.edu.tr, Yazar, bu çalışmaya doğrudan katkı sunmamış; Marmara Üniversitesi Lisansüstü Eğitim-Öğretim ve Sınav Yönetmeliği’nin 27. maddesi gereği makalede ortak yazar olarak yer almıştır. 
in certain forms; it can also be stated that this situation will result in individuals not benefiting from an effective judicial way. In particular, it can be said that there is a legal interest in determining certain legal issues by applying judicial means in the face of administrative procedures oriented towards various issues and benefiting from the presumption of compliance with law. In this sense, despite the necessity to resolve the disputes concerning public law in the administrative judicial system, it can be stated that there is no legal opportunity in the administrative procedure law to address the legal interest in question, in view of the fact that the evidence finding institution only focuses on the determination of material facts and the types of cases are limited. In this direction, first of all, the concept of declaratory cases and the field of application will be defined and then the question of the necessity of declaratory cases in administrative procedure law will be examined.

Keywords: Administrative Act, Administrative Case, Declaratory Case, Determination of Evidence, Legal Interest.

\section{GiRiş}

İdari işlemlerin farklı pek çok konuya yönelmesi ve hukuk düzeninde sonuç doğurarak muhataplarının hukuki durumlarını etkileyebilmeleri karşısında, bunlardan doğabilecek uyuşmazlıkların çözümünde mevcut dava türlerinin yanında tespit davalarının üzerine yoğunlaşılması bir gereklilik olarak belirmektedir ${ }^{1}$. Gerçekten, Türk idari yargılama hukuku bakımından tespit davalarının bulunmayışının yarattığı boşluk yanında, bu dava türünün hukuk sistemine yabancı kaldığı da ifade edilebilecektir ${ }^{2}$. Buna koşut biçimde, doktrinde tespit davalarının yorum davalarını kapsayan bir dava türü olarak; "İdari Yargılama Usulü Kanunu’nda yer almamasına ve bu nedenle ayrı bir dava türü olarak kabul edilemeyeceği yolunda yaygın kanıya rağmen, idari yargı bakımından bir gereksinim ve gereklilik olduğu ileri sürüldüğ̈̈̈nden, konunun güncelliğini yitirmediği” ifade edilmektedir ${ }^{3}$.

Tespit davaları, esasen bir hukuki ilişkinin var olup olmadığını yahut hukuki ilişkinin içeriğinin ve anlamının ne olduğunun belirlenmesi maksadıyla açılan davalar olarak karşımıza çıkmaktadır ${ }^{4}$. 2577 sayılı İdari Yargılama Usulü Kanunu (“IYUK”) md.2 kapsamında öngörülmemesine rağmen, kimi hallerde bir hukuki ilişkinin tespitine yönelik bireylerin menfaati bulunabilmektedir ${ }^{5}$. Bu noktada söz konusu gereksinimin; (i). adli yargı düzeninde açılacak davalarla, (ii). delil tespiti kurumuyla karşılanabileceği yönünde bir sav ileri sürülebilir. Ne var ki, tespit davalarının kimi hallerde kamu hukuku hükümlerine tabi hukuki ilişkileri konu edinmesi, bu iddianın geçerliliğini oldukça düşündürmektedir6́. Zira 1982 Anayasası (“AY”) md.125 ve md.155 hüküm

\footnotetext{
ERDOĞDU, Ahmet, “Tespit Davası”, Danıştay Dergisi (DD.), Sayı:3, 1971, s.13.

ERDOĞDU, Tespit Davası, s.13.

3 ODER, Burak/AYANOĞLU, Taner, “Yorum ve Tespit Davaları”, İdari Yargının Yeniden Yapılandırılması ve Karşılaştırmalı İdari Yargılama Usulü Danıştay 133. Yıl Sempozyumu, Danıştay Yayınları, Ankara, 2003, s.105.

4 KURU, Baki, Tesbit Dâvaları, AÜHF Yayınları, Ankara, 1963, s.18; GÖZÜBÜYÜK, A. Şeref/TAN, Turgut, İdare Hukuku Cilt-II: İdari Yargılama Hukuku, 7.Baskı, Ankara, 2014, s.247.

5 ÇAĞLAYAN, Ramazan, İdari Yargılama Hukuku, 11.Baskı, Seçkin Yayıncılık, Ankara, 2019, s.718.

6 Nitekim bu hallerde Uyuşmazlık Mahkemesi, "eda davasının öncüsü niteliğinde bir özel hukuk ilişkisinin tespitine iliş̧in olmayan, ancak idari usuller çerçevesinde idarece değerlendirilmesi gereken bir tespitin yapılması istemiyle müstakil olarak açılan tespit davasına bakılıp bakılamayacağı konusunda idari yargı yerinin görevli bulunduğu(na)" karar vermektedir: UM. E.2000/58, K.2001/4, T.26.02.2001, RG.18.06.2001-24436; UM. E.2002/102, K.2002/100, T.23.12.2002, RG.27.03.2003-
} 
leri $^{7}$ bir arada değerlendirildiğinde; kamu hukuku ilişkisi olarak ifade edilecek hususların ${ }^{8}$ adli yargı düzenine bırakılması, bu konuda görevli ve uzman yargı yeri tarafından gerekli incelemenin yapılamaması neticesini doğuracaktır ${ }^{9}$. Bu nedenle çalışmanın devamında öncelikle, idari yargılama hukukunda bu davaların uygulama alanına değinilecek; sonrasında söz konusu dava türünün idari yargılama hukukunda gerekliliği meselesi yargı kararları ışı̆̆ında irdelenecektir.

\section{TESPIT DAVALARININ KAPSAMI VE UYGULAMA ALANI}

IYYUK’ta açıkça öngörülmeyen tespit davaları 6100 sayılı Hukuk Muhakemesi Kanunu md.106 hükmünde açık biçimde düzenleme imkanı bulmuştur ${ }^{10}$. Buna göre, "Tespit davası yoluyla, mahkemeden, bir hakkın veya hukuki ilişkinin varlı̆̆ının ya da yokluğunun yahut bir belgenin sahte olup olmadığının belirlenmesi talep edilir. Tespit davası açanın, kanunlarda belirtilen istisnai durumlar dışında, bu davayı açmakta hukuken korunmaya değer güncel bir yararı bulunmalıdır. Maddi vakıalar, tek başlarına tespit davasının konusunu oluşturamaz". Bu doğrultuda "hukuken korunmaya değer güncel menfaati bulunan” kişiler tarafından açllacak tespit davalarının “maddi vakıalardan" ziyade "bir hakkın ya da hukuki ilişkinin var olup olmadığ açıkça ortaya konulmuştur ${ }^{11}$. Esasen, bu konuda her ne kadar farklı görüşler ileri sürülse de idari yargılama hukukunda uygulanabilecek tespit davaları bakımından da aynı esasen geçerli olduğu ifade edilebilecektir ${ }^{12}$. Zira idari yargılama hukukunda halihazırda delil tespiti kurumun yer verilmiş olup, maddi vakıaların tespiti bu sayede yapılabilmektedir.

Oysa aşağıda değinileceği üzere, bu müessesenin tek başına hukuki ilişkilerin varlığı ya da yokluğunun tespitinde işlevsel olmayacağının belirtilmesi gerekir. Zira idari yargılama hukuku

25061; UM. E.2015/76, K.2015/95, T.02.03.2015, RG. 27.03.2015-29308 (Mükerrer); UM. E.2012/291, K.2013/479, T.08.04.2013, RG.21.05.2013-28653 (Mükerrer); UM. E.2014/568, K.2014/725, T.14.07.2014, RG.26.07.2014-29072 (Mükerrer).

7 AY md.125/1 “İdarenin her türlü eylem ve işlemlerine karşı yargı yolu açıktır (...)”. AY md.155/1 “Danıştay, idarî mahkemelerce verilen ve kanunun başka bir idarî yargı merciine bırakmadiğı karar ve hükümlerin son inceleme merciidir. Kanunla gösterilen belli davalara da ilk ve son derece mahkemesi olarak bakar".

8 Özellikle, doktrinde Erkut'un aktardığı üzere; "bir idari işlemin tesisinin sağlanması amacının ön planda olduğu haller bakımından” kamu hukuku ilişkisinin varlığından bahsedilebilecektir. ERKUT, Celal, “Tespit Davasının İdarî Bir Dava Türü Olarak Kabul Edilip Edilemiyeceği Sorununa Uyuşmazlık Mahkemesinin Yaklaşımı”, İdare Hukuku ve İlimleri Dergisi (İHİD), Cilt:11, Sayı:1-3, 1990, s.7.

9 ERKUT, Celal/SOYBAY, Selçuk, Anayasa ve İdari Yargılama Hukukuna İlişkin Kanunlar, 5.Baskı, Beta Yayıncılık, İstanbul, 2001, s.235. Ayrıca bkz. ERKUT, Celal, “İ.Y.U.K. Çerçevesinde İdari Dava Türleri ve Bazı Usuli Değişiklikler”, IÜHFM, Cilt:51, Sayı:1-4, 1985, s.222. Bununla birlikte doktrinde Günday’a göre, "idari işlem ve eylemlerle uzaktan ya da yakından ilgili olmakla beraber, bu işlem ve eylemlerin hukuka uygunluk denetimlerinin yapılmadığı davaların adlî yargının görev alanına sokulmasına anayasal bir engel yoktur". GÜNDAY, Metin, "İdari Yargının Görev Alanının Anayasal Dayanakları", Anayasa Yargısı Dergisi, Sayı:14, 1997, s.354. Bu anlamda tespit davalarında bir idari işlem ya da eylemin hukuksal denetimi yapılmadığından böyle bir sonuca ulaşılabilirse de "tespit davalarının" adli yargıda görüleceğine ilişkin genel ve kesin bir kanun hükmü bulunmadığından; söz konusu uyuşmazlıkların çözümünde kaide olarak idari yargı düzeninin görevli olduğu belirtilecektir.

10 Dolayısıyla “tespit davalarının” hukukumuzda hiç yer almadığı yönünde ileri sürülen ifade, artık geçerliliğini yitirmiştir. KAPLAN, Gürsel, İdari Yargılama Hukuku, Ekin Yayıncılık, Bursa, 2016, s.148.

11 KALABALIK, Halil, İdari Yargılama Hukuku, 13.Baskı, Seçkin Yayıncılık, Ankara, 2019, s.158-159.

12 GÖZÜBÜYÜK/TAN, s.247. 
bakımından da bireylerin tespit davasının açılması hususundaki menfaati salt "maddi olgunun" tespitine yönelmemektedir ${ }^{13}$. Bu noktada, hukuki durumların tespitine yönelen uyuşmazlıklar bakımından delil tespiti kurumunun bu ihtiyacı karşılamadığı açıktır ${ }^{14}$. Bununla birlikte bu düşünce metodolojisi, tespit davalarında maddi olguların hiçbir durumda belirlenemeyeceği biçiminde de yorumlanmamalıdır. Zira çoğu hukuki ilişkinin temelinde bir maddi olgunun/olguların yer aldığı göz önüne alındığında; tespit davalarında da arka planda maddi olgunun tespit edildiği söylenebilir ${ }^{15}$. Ne var ki, bu durumun varlığı tespit davalarının uygulama alanının sadece "maddi olguların tespitiyle" sınırlandırıldığını göstermemektedir ${ }^{16}$. Nitekim söz konusu durumlarda dahi sadece maddi olguların tespitine yönelmekle yetinilmeyip, bu tespitlerin esasen "bir hakkın ya da hukuki ilişkinin olup olmadığına" yönelik olduğu ifade edilecektir ${ }^{17}$. Dolayısıyla tespit davalarının uygulama alanını "maddi olguların tespiti" biçiminde dar bir çerçevede ele alınmaması gerekmektedir.

\section{TESPITT EDİCI İŞLEMLERLE BAĞLANTILI OLARAK TESPITT DAVALARININ ÖZELLİKLERINIIN ORTAYA KONULMASI}

İdarenin pozitif hukuk kurallarıla kendisine verilen görevleri yerine getirirken kamu gücü kullanımına bağlı olarak tesis ettiği hukuki araçlardan biri olan "idari işlemler" kimi hallerde maddi olgunun ya da hukuki durumun tespitine yönelebilmektedir ${ }^{18}$. Bu kapsamda "tespit" kavramının anlam olarak belirli hususları "subüt etmeye, sabitlemeye yöneldiğ $i{ }^{19 "}$ "gözetildiğinde; idarenin idari işlev kapsamında ${ }^{20}$ ortaya koyduğu irade açıklamasına bağlı olarak o anki maddi olgunun veya hukuki durumun sabitlenmesi söz konusu olabilmektedir. Burada, idarenin iradesi ilgili maddi olgunun ya da hukuki durumun tespit edilmesine yönelmekte ve bununla yetinmektedir ${ }^{21}$. Bununla birlikte hukuk düzeni kimi hallerde söz konusu tespitlere birtakım hukuki sonuçlar da bağlayabilir ${ }^{22}$.

13 Nitekim IYYUK md.58/1 uyarınca "Taraflar, idari dava açtıktan sonra bu davalara ilişkin delillerin tespitini ancak davaya bakan Danıştay, idare ve vergi mahkemelerinden isteyebilirler". Bu anlamda delil tespiti yalnızca "maddi olguların" saptanması çerçevesinde ele alınabilecek bir hukuki müessese olarak karşımıza çıkmaktadır. Bu konuda bkz. YASİN, Melikşah, İdari Yargılama Usulünde İspat, On İki Levha Yayıncılık, İstanbul, 2015, s.144.

14 ÇAĞLAYAN, s.369.

15 ODER/AYANOĞLU, Yorum ve Tespit Davaları, s.132.

16 CANDAN, Turgut, “Tespit Davası ve İdari Yarg1", DD. Sayı:72-73, 1989, s.3; DURSUN, Hasan, "İdari Yargıda Tespit Davasına Yer Verilmesi Bir Zorunluluktur", Terazi Hukuk Dergisi, Sayı:24, 2008, s.112.

17 ERDOĞDU, Tesbit Davası, s.26.

18 KARAHANOĞULLARI, Onur, İdarenin Hukukla Kavranması: Yasallık ve İdari İşlemler, 4.Baskı, Turhan Kitabevi, Ankara, 2019, s.293-294. Ayrıca bkz. SCHENKE, Wolf-Rüdiger, Verwaltungsprozessrecht, 12.Baskı, C. F. Müller Verlag, Heidelberg, 2009, s.67.

19 DEVELLIOĞLU, Ferit, Osmanlıca-Türkçe Ansiklopedik Lugat, Doğuş Matbaası, Ankara, 1962, s.1309.

20 İdari işlev kavramının tanımı ve idari işlemlerin idari faaliyetlerin yürütümü sırasında tesis edilen hukuki araçlar olduğu hakkında bkz. ÖZAY, İl Han, Günışı̆̆ında Yönetim, Filiz Kitabevi, İstanbul, 2004, s.416-417.

21 Ancak, bu durumdan hareketle tespit edici işlemlerin yalnızca enformel nitelikte işlemler olduğu sonucu çıkarılmamalıdır. Nitekim bu işlemler bakımından da yetkili idari makamın "tespit etmeye yönelen irade açıklaması" bir "değerlendirme" süreci içerebilmekte ve bu doğrultuda muhatapları üzerinde hukuki sonuçlarını doğurabilmektedir. Bkz. DEFOORT, Benjamin, La décision administrative, LGDJ, Paris, 2015, s.239.

22 Örneğin, yetkili idari makamlar tarafından yapılan riskli yapı tespiti, riskli alan tespiti, bir yapının ruhsata tabi olmadığının tespiti, bir yerin mera, yaylak ve kışlak arazisi olup olmadığının tespiti gibi işlemler neticesinde nesnelerin yaratılan statülere girmesi söz konusu olmaktadır. Bu doğrultuda idari makam tarafından "tespite yönelik irade açıklamasının dışavurumu" neticesinde, işlemin muhataplarının daha önce hukuk düzeninde öngörülen statülere 
Bu nedenle tespit edici işlem kavramının belirli hallerde muhatabı üzerinde hukuki sonuç doğuran ve buna bağlı olarak etki üreten nitelikte olduğu ifade edilebilecektir ${ }^{23}$. O halde, tespit edici işlemlerin hukuka uygunluk karinesinden yararlanması ve sabitlediği hususlara bağlı biçimde hukuk düzeninde etki üretebilmesi karşısında menfaati olumsuz biçimde etkilenen yahut hakkı ihlal edilen kişilerin idari yargıda dava açabileceğinin kabulü gerekecektir ${ }^{24}$. Nitekim bu sebepledir ki; Danıştay’ın bazı kararlarında tespit edici işlemlerin dava konusu edilebildiği görülmektedir ${ }^{25}$. Bu doğrultuda tespit edici işlemlerle içeriği saptanan bir hususun, bireyin hukuki menfaati bulunduğu ölçüde idari yargıda dava konusu olabileceğini belirtmiş bulunmaktayız.

Bununla birlikte, bireylerin açacakları dava türleri bakımından İYUK md.2 hükmünün dar manada yorumlanması nedeniyle tespit edici işlemler, tespit davasına konu edilememektedir ${ }^{26}$. İdare hukukunda tespit edici işlemlerin yöneldiği hususların genellikle kamu hukuku alanını ilgilendirmesi, bu bağlamda kurulan ilişkinin "kamu hukuku ilişkisi” olarak nitelendirilmesi söz konusu olsa da tespit davası formatında bir dava türünün bulunmadığı şeklindeki görüş, bu işlemlerin "iptal ya da tam yargı davası" biçiminde sıkıştırılmış bir sistemde incelenmesine neden olmuştur ${ }^{27}$. Bu noktada şu çıkarımlarda bulunmak mümkündür: (i). Yetkili idari makam tarafından tespit edici işlemin tesis edilmesi neticesinde bir kamu hukuku ilişkisinin kurulması söz konusu ise, söz konusu uyuşmazlı̆̆ın çözüm yeri adli yargı olamayacağından; idari yarg1 düzeninin görev alanına giren bir halin varlığı söz konusudur ${ }^{28}$. (ii). İdari yargı düzeninde İYUK md.2 kapsamında belirtilen dava türleri arasında "tespit davasına" yer verilmediğinden; dar bir yorumla kamu hukuku ilişkisinin varlı̆̆ı ya da yokluğuna dair davalar tespit davası formatında

girmesi veya çıkması gündeme gelebilmektedir. Bu husus aynı zamanda yargı kararlarında da etkisini göstermektedir; bkz. D6D. E.2019/7992, K.2019/14605, T.18.12.2019, (http://www.kazanci.com, Anılış: Kazancı İçtihat Bilgi Bankası), Erişim T.19.03.2020; D8D. E.2014/8739, K.2019/6877 T.11.07.2019, Kazancı İçtihat Bilgi Bankası, Erişim T.19.03.2020; D14D. E.2016/11073, K.2019/761, T.31.01.2019, Kazanc1 İçtihat Bilgi Bankası, Erişim T.19.03.2020; D6D. E.2019/7966, K.2019/10375, T.06.11.2019, Kazancı İçtihat Bilgi Bankası, Erişim T.19.03.2020. Ayrıca bkz. GÖZLER, Kemal, İdare Hukuku Cilt-II, 3.Baskı, Ekin Yayınevi, Bursa, 2019, s.792.

23 Özellikle idari makamların tespit edici işlemleri tesis ederken irade açıllaması "kanunların öngördüğ̈̈ hukuki sonuçların belirlenmesinde yattı̆̆ından"; söz konusu tespitlerin "sabitlediği maddi olgu veya hukuki durumların" muhatabı üzerinde hukuki sonuç doğurması ve bu bağlamda etki üretmesi söz konusu olabilmektedir. Bkz. BULL, Hans Peter/MEHDE, Veith, Allgemeines Verwaltungsrecht mit Verwaltungslehre, 8.Baskı, C. F. Müller, Heidelberg, 2005, s.301.

24 AUBY, Jean-Bernard, "Administrative Law in France”, Administrative Law of the European Union, Its Member States and the United States (A Comparative Analysis) (ed. SEERDEN, René/STROINK, Fritz), Intersentia, Antwerpen-Groningen, 2002, s.79. Ayrıca bkz. FIŞ ÜSTÜN, Gül, "Yatırımcıları Koruma Fonu Tarafından Tesis Edilen İdari Para Cezası Bildirim Tutanaklarının Niteliği”, Hacettepe Üniversitesi Hukuk Fakültesi Dergisi, Cilt:1, Sayı:2, 2011, s.70.

25 D14D. E.2011/5212, K.2011/7, T.01.06.2011, (https://www.lexpera.com.tr, Anılış: Lexpera İçtihat Bilgi Bankası), Erişim T.01.11.2019; D2D. E.2016/2337, K.2018/6381, T.15.11.2018, Kazanc1 İçtihat Bilgi Bankası, Erişim T.03.03.2020; D15D. E.2013/4617, K.2015/1969, T.07.04.2015, Kazancı İçtihat Bilgi Bankası, Erişim T.03.03.2020; D6D. E.2002/1915, K.2003/4413, T.22.09.2003, Kazancı İçtihat Bilgi Bankası, Erişim T.03.03.2020.

26 ULUSOY, Ali D., İdari Yargılama Hukuku, Yetkin Yayıncilık, Ankara, 2020, s.83; KARAHANOĞULLARI, Onur, İdari Yargı İdarenin Hukukla Zorlanması (Yargı Kararlarına Dayalı Bir İnceleme), Turhan Kitabevi, Ankara, 2019, s.229-230; ERGEN, Cafer, İdari Yargı Davaları, Seçkin Yayıncılık, Ankara, 2008, s.125.

27 Bkz. ERKUT, Tespit Davasının İdarî Bir Dava Türü Olarak Kabul Edilip Edilemiyeceği Sorununa Uyuşmazlık Mahkemesinin Yaklaşımı, s.8.

28 UM. E.1991/43, K.1991/44, T.23.12.1991, RG.13.02.1992-21141; UM. E.2015/76, K.2015/95, T.02.03.2015, RG.27.03.2015-29308 (Mükerrer); UM. E.2002/13, K.2002/30, T.24.06.2002, (http://www.uyusmazlik.gov.tr, Anılıș: UM. İçtihat Bilgi Bankası, Erişim T.30.10.2019. 
irdelenemeyecektir. (iii). Maddi olguların tespiti, yargılama sürecinde delil tespiti kurumundan yararlanarak gerçekleşebilirse de hukuki ilişkinin varlığ 1 veya yokluğunun tespitinde bu müessese yetersiz kalmaktadır. (iv). Tespit edici işlemlerin hukuk düzeninde doğurduğu sonuçların hukuki sonuç doğurmaya başladığı andan itibaren giderilmesi iptal davalarıyla mümkün olsa da bireylerin sadece "kamu hukuku ilişkisinin tespiti bakımından menfaatinin" bulunduğu durumlarda iptal davaları, yetersiz kalacaktır ${ }^{29}$. Zira belirli hallerde bireylerin davayı açma konusundaki hukuki menfaati o hukuki ilişkinin tespitine yönelebilmektedir ki; bu ihtimalde "istenen" işlemin iptal edilerek hukuk düzenindeki etkilerinin baştan itibaren silinmesi değildir. Bu anlamda doktrinde Erkut'un vurguladığı üzere, şu hususu da gözden kaçırmamak gerekir: IYYUK md.2'de dava türlerinin sayılmış olması, AY md.155 hükmü göz önüne alındığında, idari yargı önüne getirilebilecek taleplerin dava formatında sınırlandırılması anlamını taşımamaktadır ${ }^{30}$. Keza Bilgen’in ifade ettiği üzere, "idari dava" ve "idari uyuşmazllk" kavramları birbirine eşdeğer olmadıklarından"31; hukuki menfaati bulunan kişilerin tespite yönelik uyuşmazlıklarını yargı merciine taşıyabilmeleri hususunda bir sınırlamanın bulunmadığından bahsedilebilecektir ${ }^{32}$. Bu anlamda bireylerin yargısal taleplerini kullanmaları bakımından var olan kısıtlama, "yargı yerinin idare yerine geçerek idari işlem niteliğinde karar verememesi" ve "yerindelik denetiminden" ibarettir ${ }^{33}$. (v). Bir an için tespit sürecinin iptal ve tam yargı davaları bakımından da işletildiği ileri sürülebilirse de ${ }^{34} \mathrm{bu}$ davaların neticesinde ortaya çıkan sonuç, "hukuki ilişkinin varliğ ya da yokluğunun tespitinden" ziyade idari işlemin iptaline ${ }^{35}$ ya da idari işlemden ya da eylemden doğan zararın tazminine yönelmekte olduğundan ${ }^{36}$ elde edilen sonuç bakımından menfaatin yine sağlanamadığı ifade

29 İptal davalarının açılması hususunda "sübjektif dava açma ehliyetini" açıklarken kullanılan "menfaat" kavramı, tespit davalarında "hukuki ilişkinin bulunup bulunmadığı" noktasında anlam kazanabilmektedir. Esasen bir hakkın ya da hukuki ilişkinin olup olmadığının tespit edilmesi ifadesi de bu konuya değinmektedir. Bu durum, iptal davaları karşısında tespit davalarına "neden ihtiyaç duyulabileceğì" sorusunun cevaplandırılması noktasında da işlevsel niteliktedir. Bu anlamda kişilerin "sübjektif hak ihlalleri" nedeniyle açacakları tespit veya iptal davalarında elde edecekleri hükümler idarenin o konuda yeniden işlem yapmasını sonuçlayabilecekse (Bkz. ÖZAY, İl Han, Günışı̆̆ında Yönetim II: Yargısal Korunma, On İki Levha Yayıncılık, İstanbul, 2010, s.269.) de "menfaatin" söz konusu olduğu hallerde durum farklılaşmaktadır. Nitekim "hukuki menfaati" bulunan kişiler tarafından tespit davası açıldığında; "sübjektif hak ihlali söz konusu olmasa dahi", elde edilecek kesin hükme bağlı olarak idarenin bu yönde yeniden işlem yapma yükümlülüğü doğacaktır. Dolayısıyla tespit davalarının konusu "olumsuz idari işlemler" olmasa dahi idareye "yol gösterici nitelikte" yargı kararı verilebilecektir. Bu hususun özellikle idari işlemin hukuki geçerliliğine etkisi bakımından uygun görüş vb. işlemler yönünden önemi hakkında bkz. DERDİMAN, R. Cengiz, İdarî Yargının Genel Esasları, 3.Baskı, Aktüel Yayıncllık, Bursa, 2014, s.91.

30 ERKUT, Celal, "İdari Yargıya Başvuru Haklarının Sınırı ve İdari Davaların Kapsamı", 2000 Yılında İdari Yargı Sempozyumu, Ankara 11-12 Mayıs 2000, Danıştay Yayınları, Ankara, 2000, s.91. Ayrıca bkz. ÇAĞLAYAN, s.426.

31 BíLGEN, Pertev, "İdari Uyuşmazlıklar, Hukuki Nitelikleri, Çözüm Usulleri”, II. Ulusal İdare Hukuku Kongresi Bildiri Özetleri, Danıştay Yayınları, Ankara, 1993, s.82. Belirtmek gerekirse Alman hukuku yönünden de "uyuşmazlı" kavramı tam olarak "dava" kavramına tekabül etmemektedir. PRÉVÉDOUROU, Eugénie, Les recours administratifs obligatoires étude comparée des droits Allemand et Français, LGDJ, Paris, 1996, s.3. İdari uyuşmazlık teriminin, karışıklığa sebebiyet vermemesi için, idari davalar dışındaki uyuşmazlıklarda kullanılmasında yarar olduğu yönünde bkz. GÖZÜBÜYÜK/TAN, s.117. Ayrıca bkz. ZABUNOĞLU, Yahya K., İdare Hukuku Cilt-II, Yetkin Yayıncılık, Ankara, 2012, s.166.

32 ÇAĞLAYAN, s.718.

33 ERKUT, İdari Yargıya Başvuru Haklarının Sınırı ve İdari Davaların Kapsamı, s.91.

34 ÇAĞLAYAN, s.718.

35 D1D. E.2004/1314, K.2005/3187, T.27.05.2005, Lexpera İçtihat Bilgi Bankası, Erişim T.24.11.2019.

36 DİBK. E.1983/1, K.1983/10, T.29.12.1983, Lexpera İçtihat Bilgi Bankası, Erişim T.24.11.2019. Yargı kararlarında da 
edilecektir. Kaldı ki, hukuki çıkarı bulunan bir kişinin lehine sonuçlanan tespit davası neticesinde elde ettiği hükme dayalı olarak idare, kişinin talebine uygun hukuki işlemi tesis edebilir ki; bu sayede kişinin ayrıca bir idari dava açmasına lüzum kalmayabilir ${ }^{37}$. Bu nedenle iptal veya tam yargı davalarında nihai karar verilirken zaten tespitin yapıldığı şeklindeki argüman ${ }^{38}$; söz konusu hukuki menfaatin sadece tespite yöneldiği hususları açıklamak bakımından yetersizdir.

$\mathrm{Bu}$ çıkarımlardan hareketle hukuki ilişkinin varlığı ya da yokluğunun saptanması bakımından idari yargılama hukukunda "tespit davası" olarak ayrı bir dava türüne yer verilmesi gerektiği söylenebilecektir ${ }^{39}$. Ancak, tespit davalarının idari yargılama hukukunda uygulama alanı bulması açısından tespit davaları neticesinde verilecek kararların idari makamlar yönünden etkisini de ele almak gerekmektedir ${ }^{40}$. Bu durumda ise iki ihtimal söz konusu olabilir: (i). tespit edici işleme yönelik idari makam tarafından herhangi bir irade açıllaması olmaksızın dava açılması, (ii). daha önce tesis edilen tespit edici işleme bağlı olarak idari yargıda tespit davasının açılması. Bu kapsamda aşağıda, söz konusu ihtimaller çerçevesinde idari yargıda "idarenin yerine geçerek işlem tesis etme yasağı"nın değerlendirilmesine geçilecektir.

\section{TESPIT DAVALARI BAKIMINDAN IDARI EYLEM VEYA IŞLEM NITELIĞINDE YARGI KARARI VERILMESI YASAĞININ DEĞERLENDIRILMESI}

AY md.125 uyarınca "Yürütme görevinin kanunlarda gösterilen şekil ve esaslara uygun olarak yerine getirilmesini kısıtlayacak, idarî eylem ve işlem niteliğinde veya takdir yetkisini kaldıracak biçimde yargı kararı verilemez”. Buna koşut biçimde IYYUK md.2'de, "idari yargı yetkisinin idari eylem ve işlemlerin hukuka uygunluğunun denetimi ile sınırlı olduğu” hususu vurgulanmıştır. Bu doğrultuda daha önce yetkili idari makamlar tarafından irade açıklamasında bulunulmayan hallerde, mahkemece ilkelden hüküm kurulması bu yasağı ihlal edebilecektir. Tespit davaları yönünden ise bunun anlamı, idari makamların yerine geçerek belirli bir maddi olgu veya hukuki durumun tespitinin hukuka aykırı olacağıdır. O halde tespit edici işlemlerle saptanması gereken bir hususun, ilk-elden mahkeme kararıyla saptanamayacağı ifade edilebilir.

Belirtmek gerekirse, idari yargılama hukukunda yargı merciinin idare yerine geçip karar alması söz konusu olmasa da bazı davalar bakımından "hukuka uygun işlemin içeriğinin saptanması" söz

uygulama alanı bulan ve tam yargı davalarını "salt tazminat talebine indirgeyen" yaklaşım sebebiyle salt tespite yönelik biçimde hüküm kurulması da engellenmiş olmaktadır. Halbuki, "idare tarafindan sübjektif hak ihlali varsa ihlal edilen hakkın iadesi” şeklinde benimsenecek yaklaşım tam yargı davalarında giderimin kimi hallerde tespitle sağlanabildiği gözetildiğinde; daha işlevsel nitelikte olacaktır. Bkz. GÖZÜBÜYÜK/TAN, s.252.

37 ERDOĞDU, Tespit Davası, s.18.

38 CANDAN, Turgut, Açıklamalı İdari Yargılama Usulü Kanunu, Maliye ve Hukuk Yayınları, Ankara, 2006, s.226.

39 ERKUT, Tespit Davasının İdari Bir Dava Türü Olarak Kabul Edilip Edilemeyeceği Sorununa Uyuşmazlık Mahkemesinin Yaklaşımı, s.13. Tespit davasının içtihat yoluyla yahut kanuni düzenleme yapılması neticesinde kabulünün gerektiği hakkında bkz. TAN, Turgut, İdare Hukuku, 7.Baskı, Turhan Kitabevi, Ankara, 2018, s.1158; ÇAĞLAYAN, s.273; TANRIVERDİ, Ayşe Almıla, "Danıştay Beşinci Dairesinin 03.02.1988 Tarih, 1987/2333 E. 1988/408 K. Sayılı Kararı Uyarınca Danıştay'ın Tespit Davasına Bakışı”, 5. İdare Hukuku Buluşması "Danıştay Kararı İncelemeleri” 4-6 Mayıs 2018, Filiz Kitabevi, İstanbul, 2019, s.114-115.

CANDAN, Tespit Davası ve İdari Yargı, s.3. 
konusu olabilmektedir ${ }^{41}$. Nitekim konuyla ilgili olarak Danıştay kararlarına göre, "vergi idaresi tarafindan, vergi mahkemelerince verilen kararlara göre tespit edilen vergi ve ceza miktarı ihbarname ile vergi yükümlüsü ya da sorumlusuna tebliğ edilmektedir ${ }^{42}$ ". Buna koşut biçimde, Danıştay’nn içtihadı kapsamında vergi davaları bakımından idari işlemin hukuka uygunluğu denetimi yanında idarece yapılacak idari işlemlerin içeriğinin belirlenmesi de söz konusu olmaktadır ${ }^{43}$. Doktrinde Duran, bu konu hakkında yüksek mahkemenin "idarenin kamu alacă̆ını daha çabuk ve basit biçimde tahsilinin sağlanması açısından” böyle bir içtihada yer verildiği düşüncesindedir ${ }^{44}$. Bununla beraber yazar, söz konusu gerekçelerden hareketle AY md.125 ve İYUK md.2 hükümlerine istisna getirilemeyeceğini ifade etmektedir ${ }^{45}$. Zira artık idari işlemin içeriği yargı yeri tarafından saptanmış olduğundan; idarece İYUK md.28 kapsamında buna uygun biçimde davranma yükümlülüğü ortaya çıkmaktadır ${ }^{46}$. Ancak, yapılacak yargısal denetim neticesinde idari yargı mercii tarafından hukuka uygun idari işlemin içeriğinin saptanması, onun yerine geçerek idari işlem niteliğinde bir kararın verildiğini göstermemektedir ${ }^{47}$. Esasen idari yargı mercii tarafından verilecek kararların "idari işlem veya eylem niteliğinde olamayacağı” gerekçesiyle bireylerin kullanabileceği yargısal olanakları bu denli kıstlamak hukuk devleti ilkesiyle de bağdaşmayacaktır ${ }^{48}$.

Bunun yanında dikkat edilirse bu davalar bakımından da önceden tesis edilen (mevcut) bir idari işlemin varlığ 1 söz konusudur. Nitekim Danıştay’n vermiş olduğu bir kararda da "henüz ortada ihtilaflı indirim oranına göre yapılmış bir tarh işlemi bulunmadığı ve bu aşamada yatırım indiriminin ne olacağına karar verilemeyeceğ $i^{49}$ " ifade edilerek bu hususa vurgu yapıldığ görülmektedir. Ancak, bir tespit edici işlem yapılmaksızın bu dava açılabilir mi sorusu bu örnekler bakımından yanıtsız kalmaktadır. Bu nedenle, (i). önceden idari makam tarafından tespit edici işlemin yapılması durumunda, tespit davasıyla belirlenen içeriğe uyma yükümlülüğü ile (ii). böyle bir işlem yokken mahkeme tarafından bir hukuki durumun varlı̆ğ ya da yokluğunun tespit edilmesinin idare üzerindeki etkisini ayırt etmek gerekecektir. O halde, bu konudaki irdelemenin; tespit edici

41 KARAHANOĞULLARI, Onur, “İdari İşlem Niteliğinde Yargı Kararları ve Vergi Davaları”, Prof. Dr. A. Şeref Gözübüyük’e Armağan, Turhan Kitabevi, Ankara, 2005, s.209.

42 DVDDK. E.2013/464, K.2013/895, T.25.12.2013, Lexpera İçtihat Bilgi Bankası, Erişim T.24.11.2019.

43 D7D. E.1984/3570, K.1985/1039, T.12.04.1985, DD. Say1:60-61, s.333.

44 DURAN, Lütfi, "İdari İşlem Niteliğinde Vergi Kararlarıyla Vergi Davalarının Çözümü (II)", Amme İdaresi Dergisi, Cilt:21, Sayı:1, 1988, s.76.

45 DURAN, s.77.

46 KARAHANOĞULLARI, İdari İșlem Niteliğinde Yargı Kararları ve Vergi Davaları, s.209.

47 KARAHANOĞULLARI, İdari İșlem Niteliğinde Yargı Kararları ve Vergi Davaları, s.209.

48 YILDIRIM, Turan, "Yargı Kararlarının Uygulanmaması Sorunu", İdari Yargının Yeniden Yapılandırılması ve Karşılaştırmalı İdari Yargılama Usulü Danıştay 133. Yıl Sempozyumu, Danıştay Yayınları, 2001, s.159. Aynı görüşte; GÜRAN, Sait, "Yargı Denetiminin Kapsamı", İÜHFM (Ord. Sulhi Dönmezer’e Armağan), Cilt 52, Sayı:1-4, 1985, s.43.

49 "Öte yandan; uygulanacak yatırım indirimi oran ve miktarının bir idari işlemle tespiti yukarıda sözü edilen 198 sayll Kanunun ilgili maddeleriyle idareye tanınmış bir yetki olup, idarece bu konuda tesis edilen idari işlemler dolayıstyla açılan davada idari yargi yerlerinin yetkisi, yatırm indirimi ile ilgili olarak idareye tanınan bu yetkinin hukuka uygun olarak kullanilıp kullanılmadığın 2577 sayll İdari Yargılama Usulü Kanununun 2. maddesinin 2. bendinde yer alan düzenleme çerçevesinde denetlemekten ibarettir. Bu bakımindan; Mahkeme kararında, davanin konusunun, yatırım indirimi oran ve miktarının tesbiti şeklinde nitelendirilmesinde de isabet görülmemiştir’. D3D. E.1986/1733, K.1986/1500, T.04.06.1986, DD. Say1:64-65, s.104-105. 
işlemlerin yapılmasından sonra açılacak tespit davaları ile böyle bir idari işlemin bulunmadığı haller bakımından ayrı ayrı yapılması daha uygun olacaktır.

\section{A. IDARI IŞLEM TESIS EDILDIKTEN SONRA AÇILACAK TESPIT DAVALARI YÖNÜNDEN}

Yetki idari makam tarafından tespite yönelik irade açıklamaları çeşitli konuları ihtiva edebilmektedir. Bu doğrultuda tespit davaları bakımından da bireylerin hukuki menfaatlerinin bulunduğu ölçüde farklı konuda taleplerin ileri sürülmesi gündeme gelebilmektedir. Örneğin, babasının şehit olduğundan hareketle ilgili mali yardımlardan yararlanmak isteyen bireyler bakımından, idarece o kişinin "şehitlik" durumunun saptanmasından sonra açılacak tespit davasında da söz konusu hukuki ilişkinin bulunup bulunmadığı irdelenecektir ${ }^{50}$. Keza, yapılacak sosyal yardımlar bakımından kişinin "bakıma muhtaç durumda olup olmadiğının tespiti” bakımından da benzer ifadelerin kullanılması söz konusu olabilecektir ${ }^{51}$. Verilen örneklerde idarenin tespite yönelik bir irade açıklaması bulunmakla birlikte, yargı organı tarafından yeniden değerlendirme yapılarak hukuki ilişkinin varlığı ya da yokluğunun tespitiyle sınırlı biçimde karar verileceği ifade edilebilir. Yani, tespit davaları bu durumda tespit edici işlemlerin yarattığı hukuki sonuçlara bağlı olarak bir değer kazanmaktadır. Buna bağlı olarak tespit davalarının içerik itibarıyla tespit edici işlemlerle kesişmesi söz konusu olabilir. İşte, bu halde idarenin yerine geçerek işlem yapma yasağının ihlal edildiğinden bahsedilebilir mi, bu sorunun cevabının irdelenmesi gerekmektedir.

Bu konuda Danıştay’ın vermiş olduğu bir karara göre, “ödenen vergilerin faiziyle birlikte iadesine hükmedilmesi istemi hakkında, Mahkemece, "182.505,00 Yeni Türk lirasının davalı İdareden alınarak davacıya verilmesine” şeklinde hüküm kurulması yerine, “...ödenen 182.505,00 YTL damga vergisinin davacıya iadesine..." denilmek suretiyle, vergi idaresi yerine geçilerek, idari işlem niteliğinde karar verilmesi sebebiyle Yargilama Hukuku kurallarma uygun olmamakla birlikte; bu husus, bozma sebebi olarak görülmemiştir ${ }^{52 " . ~ B i r ~ b a s ̧ k a ~ D a n ı s ̧ t a y ~ k a r a r ı n d a ~ i s e, ~ “ d o ̈ n e m ~ m a t r a h ı n ı n ~ t a k d i r i ~ g e r e k t i g ̆ i ~}$ sonucuna varan mahkemenin matrahı tayin ve tesbit etmesi gerekirken, takdir komisyonu kararın iptal ile yetinmesinde isabet görülmemiştir ${ }^{53 "}$. Dolayısıyla AY md.125 ve IYYUK md.2 uyarınca idari işlem ve eylem niteliğinde yargı kararı verilemezse de "tespite yönelen yargı kararlarında" bu husus ayrı bir nitelik kazanabilmektedir.

Bu doğrultuda, yargı mercii tarafından verilen kararın hukuki etkisi ile idarenin kararı uygulaması arasında bir ayrımın varlığı söz konusu olmaktadır ${ }^{54}$. Tespit davalarında kararın hukuksal etkisi, bir hukuki ilişkinin varlığ 1 ya da yokluğunu saptamaktan ibarettir. Ancak, tespit edici işlemin ve tespit davasının ayrı sonuçlara ulaşması halinde, tespit davasında verilen kararın idareyi belirli yönde işlem yapma yükümlülüğüne soktuğundan bahsedilebilir. Dolayısıyla bu ihtimalde

50 ÖZKOL, Adil, Uyuşmazlık Mahkemesi Kararları Açısından İdari Yargının Görev Alanı, Sevinç Matbaası, Ankara, 1970, s.24.

51 D10D. E.2012/2974, K.2016/1083, T.29.02.2016, Lexpera İçtihat Bilgi Bankası, Erişim T.24.11.2019.

52 D7D. E.2009/1034, K.2010/1665, T.07.04.2010, (https://legalbank.net), Erişim T.20.03.2020.

53 D4D. E.1983/2799, K.1985/1246, T.24.04.1985, DD. Say1:60-61, s.197.

54 KARAHANOĞULLARI, İdari Yargı İdarenin Hukuka Zorlanması, s.153. 
idarenin yerine geçerek işlem tesis etmekten ziyade idareye "yol gösteren" bir halin varlığı söz konusudur ${ }^{55}$. Belirtmek gerekirse, yargı kararlarında "idareye yol gösterilmesi idari işlem ve eylem niteliğinde yargı kararı verilmesi yasağı kapsamında değerlendirilmemektedir ${ }^{56 "}$. Nitekim bu durum, olumsuz idari işlemlerin iptali ya da yürütmesinin durdurulması konusunda da ortaya çıkabilmektedir ${ }^{57}$. Buna koşut biçiminde tespit davası neticesinde idarenin yükümlülüğü, mahkemece tespit edilen "hukuki gerçekliğe" göre işlemin yeniden değerlendirmek ve buna göre tesis etmek olacaktır ${ }^{58}$.

Burada, tespit davası neticesinde verilecek kararla hukuki ilişkinin varlığı ya da yokluğu konusu sabitlenmiş olacağından; iptal davasından farklı olarak sadece hukuka uygunluk değerlendirmesi yapılmayacaktır ${ }^{59}$. Bu anlamda bir hukuki ilişkinin varlığ ya da yokluğunun saptanmasına bağlı olarak oluşan gereksinimin güvenilir ve hızlı biçimde sağlanması açısından tespit davalarının daha etkili olduğu söylenebilecektir. Nitekim tespit davası, ayrı bir dava türü olarak bir uyuşmazlı̆̆ın çözümü bakımından yapılan tespitten ayrı biçimde, "müstakil olarak" yapılan saptamayı ifade etmektedir ${ }^{60}$. $\mathrm{Bu}$ kapsamda tespit edici işlemin unsurları yönünden hukuka uygunluk değerlendirmesinden ziyade, yöneldiği hukuki ilişkinin var olup olmadığını kavrayabilmenin yarar sağladığından tabii olarak bahsedilebilecektir.

$\mathrm{Bu}$ çerçevede örneğin, tespit edici işlemden farklı olarak tespit davası neticesinde bir kişinin emekli olduğuna karar verildiğinde; idarece o kişinin emekli statüsüne bağlı haklardan yararlanması için tespit edici işlem yapma ve uygulama yükümlülüğü doğmuş olacaktır ${ }^{61}$. İşte bu noktada, tespit davası neticesinde idarenin yerine geçerek karar alma yasağının ihlalinden değil ${ }^{62}$ ve fakat "kararın hukuksal etkisi ve uygulanması" hususlarına atıfta bulunmak gerekmektedir ${ }^{63}$. Bu doğrultuda tespit davaları neticesinde verilen kararların hukuki etkisinin, idareyi belirli yönde işlem yapmaya zorladığından bahsedilebilecektir ${ }^{64}$. Bununla birlikte idarenin görevli yargı mercii tarafından verilen yürütmenin durdurulması yahut iptal kararlarını dahi uygulamama eğiliminde olmas ${ }^{65}$, tespit davası neticesinde elde edilecek kararların uygulanması yönünden de soru işaretleri yaratmaktadır.

55 GÖZÜBÜYÜK/TAN, s.543.

56 AKYILMAZ, Bahtiyar/SEZGINNER, Murat/KAYA, Cemil, Türk İdari Yargılama Hukuku, Savaş Yayınevi, Ankara, 2018, s.78.

57 AKYILMAZ/SEZGINER/KAYA, s.78.

58 YAŞAR, H. Nuri, İdari Yargı Kararlarının Etkinleștirilmesi Arayışında İdari Yargı İdari Yargı̨̧ Yargısal Emir, 2.Baskı, On İki Levha Yayıncilık, İstanbul, 2013, s.127.

59 DERDIMAN, s.91.

60 KAPLAN, İdari Yargilama Hukuku, s.149.

61 TAN, Turgut, "Sinav Notları ve Yargisal Denetim”, DD. Sayı:18, 1975, s.192.

62 Danıştay’ın, yargı mercii tarafından verilen kararın yarattığı hukuksal etki ile idarenin yerine geçerek işlem yapma hususunu birbirine karıştırdığı kararlara da rastlanılmaktadır. Örneğin, bir sözlü sınavın yapılması neticesinde kişinin başarısız olduğuna ilişkin işlemin iptali halinde, yargı yeri tarafından “yeniden sınav yapılması konusunda idareye bir emir verilmesi yahut idarenin yerine geçerek işlem yapılması" söz konusu olmayacak ve fakat idare, bu kararın yarattığı hukuki etki ve sonuçlara uygun davranma yükümlülüğü altına girecektir. Bkz. D11D. E.1974/5670, K.1976/752, T.26.02.1976, DD. Sayı:24-25, s.507.

63 KARAHANOĞULLARI, İdari Yargı İdarenin Hukuka Zorlanması, s.154.

64 ÖZSOYLU, Kırdar, “İdari Yargıda Tesbit Davalarının Yeri”, DD. Sayı:68-69, 1988, s.139.

65 ERKUT, İdari Yargıya Başvuru Haklarının Sınırı ve İdari Davaların Kapsamı, s.89. 


\section{B. IDARI işLEMIN TESIS EDILMEDIĞi HALLERDE AÇILACAK TESPIT DAVALARI YÖNÜNDEN}

Yetkili idari makamlar tarafından maddi olgunun veya hukuki durumun tespit edilmesi neticesinde işlemin muhatapları üzerinde doğan olumsuz sonuçlara bağlı olarak idari yargıda tespit davasının açılması gündeme gelebilecektir. Ancak, böyle bir işlem yoksa, bu durumda menfaati bulunan kişilerin mahkemeye başvurarak elde edeceği kararın idare bakımından sonuçlarının ne olduğunun açıklanması gerekmektedir. Bu kapsamda doktrinde Candan, idari işlem ortada yokken tespit davası ile bir durumun saptanmasının idari rejime ters düştügünü ve bunun idarenin görev alanına müdahale teşkil ettiğini ifade etmektedir ${ }^{66}$. Belirtmek gerekirse, ortada bir tespit edici idari işlem yokken açllacak tespit davası neticesinde elde edilen hüküm, maddi olguların saptanmasını sağlamayacaktır ${ }^{67}$. Bu bağlamda idarenin herhangi bir tasarrufu bulunmaksızın maddi olguların saptanmasına yönelik ${ }^{68}$ delil tespiti kurumunun işletilmesi düşünülebilecekse de yukarıda değinildiği üzere, bunu bir dava türü olarak kabul etmenin imkanı bulunmamaktadır ${ }^{69}$. Dolayısıyla yazarın, bu hallerde açılacak dava neticesinde "maddi olguların ilk-elden yargı kararıyla saptanmış olacağı" ve idarenin bu yönüyle belirli sınırlara itileceği düşüncesi yersizdir. Zira maddi olguların doğrudan saptanmasına yönelik bir tespit davasının kabulü, söz konusu müessesenin varlığıyla çelişik bir durum arz edecektir ${ }^{70}$.

Ancak, hukuki ilişkilerin tespitinde maddi olguların değerlendirilmesi de söz konusu olduğundan; yargı mercii tarafından bir hukuki ilişkinin varlığı ya da yokluğunun saptanması, kimi hallerde idareye başkaca bir seçenek bırakmayabilir ${ }^{71}$. Örneğin, bir kişinin vatandaşlık statüsünün tespiti bakımından idari yargı mercii tarafından karar verildiğinde; bu karar AY md.138 ve IYYUK md.28 uyarınca idare için bağlayıcı olacağından ${ }^{72}$, idarece maddi olguların saptanması neticesinde farklı bir sonuca varılsa da yargı kararını uygulama yükümlülüğü söz konusu olacaktır. Başka bir anlatımla bu ihtimalde idare - önceden herhangi bir irade açıklamasında bulunmadığı halde - sadece "yargı kararlarına uyma yükümlülüğ̈̈" ile sınırlandırılmış bir çerçevede irade açıklamasında bulunacaktır ${ }^{73}$. İște, hukuk

66 CANDAN, Tespit Davası ve İdari Yarg1, s.4.

67 ÖZSOYLU, s.139.

68 ÖZAY, Yargısal Korunma, s.292-293; YASIN, İdari Yargılama Usulünde İspat, s.146; SUNAY, Süheyla Ş., İdari Yargılama Usulüne Hakim Olan İlkeler Karşısında İsbat ve Delil Hususları, Kazancı Yayınları, İstanbul, 1997. s.36.

69 ÇAĞLAYAN, s.369.

$70 \mathrm{Bu}$ anlamda söz konusu tartışma tespit davası temelinde değil; maddi olguların tespitine yönelen ve bağımsız dava türü olarak yorumlanamayacak "delil tespiti" kurumu çerçevesinde yapılmalıdır. Bkz. ERDOĞDU, Tesbit Davaları, s.28; DERDIMAN, s.294; YASIN, İdari Yargılama Usulünde İspat, s.146.

71 ÖZSOYLU, s.139.

72 Nitekim AY md.138 uyarınca yargı kararlarına uyma zorunluluğu bakımından herhangi bir istisnanın getirilmediği görülmektedir. Bu anlamda bir idari işlemin hukuka aykırllğını saptamanın yanında o hukuki ilişkinin varlığı ya da yokluğunu belirleyen tespit davaları bakımından da söz konusu kararların idare için bağlayıcı olacağından ve idarenin IYUK md.28 kapsamında söz konusu yargı kararını gecikmeksizin uygulama yükümlülüğünün bulunduğundan bahsedilecektir. YILDIRIM, Turan, "Yargı Kararlarının Uygulanmaması Sorunu”, İdari Yargının Yeniden Yapılandırılması ve Karşlaş̧ırmalı İdari Yargılama Usulü Danıștay 133. Yıl Sempozyumu, Danıştay Yayınları, 2001, s.158-159. Esasen devletin bu konuda pozitif yükümlülüklerini yerine getirmesi, "hak arama özgürlüğü" ve "adil yargılanma hakkı" ile doğrudan ilgilidir. İNCEOĞLU, Sibel, "Hukuk Devletinin İnsan Hakları Avrupa Mahkemesi ve Türk Anayasa Mahkemesi Kararlarında Tezahürü: Karşılaştırmalı Bir Çalışma”, Anayasa Hukuku Dergisi, Cilt:4, Sayı:7, 2015, s.98.

73 İdari yargılama hukukunda, kişilerin mahkemeye "doğrudan talepte bulunduğu hallerde işin esası bakımından verilecek kararları" idari işlem veya eylem niteliğinde yargı kararı verilmesi yasağının ihlalini teşkil ettiği hakkında bkz. 
düzeninde yaşanabilecek bu gibi çatışmaların önlenmesi ve idarenin yargı kararlarına uyma eğiliminin artırılması bakımından ${ }^{74}$ tespit davalarının, Alman idari yargılama hukukunda olduğu gibi ${ }^{75}$, idari işlemin yapılış süreciyle birlikte değerlendirmek gerekmektedir ${ }^{76}$. Başka bir deyişle, "idarenin yapmakla yükümlü olduğu bir tespit edici işlemi yapmaması hali veya yaptı̆̆ tespit edici işlemi” tespit davasına konusu edilebilecektir ${ }^{77}$. Nitekim doktrinde Tan da "hukuksal durumu saptama görevinin idareye bırakılmadığı durumlarda (=yükümlü olmadı̆̆ı durumlar)” doğrudan doğruya idari yargı yerine başvurulabileceğini; ancak, hukuksal durumun saptanması hususunda idareye "pozitif bir yükümlülük getirilmişse” bu durumda öncelikle idareye başvurması gerektiğini ifade etmektedir ${ }^{78}$.

$\mathrm{Bu}$ anlamda, aksi durumun kabulünün AY md.125 hükmüne aykırılık teşkil edebileceğinden bahsedilebilir $^{79}$. Esasen, idari yargilama hukukunda idari davalardan bahsedilirken; davaya konu olan bir idari işlem, idari eylem yahut idari sözleşmenin varlığına referans verilmektedir ${ }^{80}$. O halde, - hukuki durumların saptanması bakımından idareye bu yönde pozitif bir yükümlülük getirilmişse ${ }^{81}$ - ayrı bir dava türü olarak tespit davalarının da bu kaideden ayrık tutulmasını haklı gösteren bir sebep bulunmamaktadır. Bu bağlamda, söz konusu hallerde idarece ilgilinin istemi reddedilmişse ya da idarenin tesis ettiği işlem ilgilileri tatmin etmiyorsa, hukuki menfaatin bulunduğu ölçüde; idari işlem ilgililerce dava konusu edilerek hukuk ilişkinin tespiti istenebilecektir ${ }^{82}$.

\section{SONUÇ}

Tespit davalarının idari yargılama hukukunda dava türleri arasında gösterilmemesi, bu dava türünün idari yargılama hukukunda uygulama alanı bulamayacağ

AKYILMAZ/SEZGINER/KAYA, s.79.

74

75

$$
\text { yap }
$$
hukukunda idari işlemin var olmadığı durumlarda "idarenin faaliyetleri karşısında yargısal korunmanın tespit davası ile sağlanabileceğini” ifade etmektedir. Hemen vurgulayalım ki; burada idari işlemin var olmadığı durum ifadesiyle kastedilen, idarece herhangi bir irade veya tutum ortaya konulmaksızın mahkemece maddi olguların tespiti değildir. Burada anlatılmak istenen esasen, idarenin bir faaliyeti kapsamında olumsuz tutumuna yönelik, bir hukuki ilişkinin varlığının ya da yokluğunun saptanmasından ibarettir. Bu nedenledir ki yazar, "bireylerin idari faaliyetler karşısında korunması" ifadesini kullanmıştır. FROMONT, Michel, "Avrupa Topluluğu’na Üye Devletlerde, İdari Kararlar Karşısında Bireylerin Geçici Olarak Korunması Sorunu” (çev. ERKUT, Celal), İHİD, Cilt:7, Sayı:1-3, 1986, s.61. İdarenin tespit yapması gerekiyorsa veya bir takdir alanı varsa, idarenin, mahkemenin hukuksal kanaatini dikkate Doktrinde Oder/Ayanoğlu’nun ifade ettiği üzere, “\$113 VwGO uyarınca, idari işlemin yapılmasının reddinin veya
yapılmamasının hukuka aykırı olduğunu tespit eden mahkeme, - eğer idarenin belirli tespitler yapması gerekmiyorsa
veya idareye bırakılmış bir takdir alanı yoksa - idarenin talep edilen işlemi yapma yükümlülüğ̈nde olduğu kararını larak işlem yapma yükümlülüğü olduğuna karar verilir”. ODER/AYANOĞLU, s.117; ERDOĞDU, Ahmet, "Almanya’da Benzer biçimde $\mathrm{AB}$ yargılama hukukunda da Can’n belirttiği üzere, maddi vakanın doğrudan tespiti yapılmamakta olup maddi olayın algılanması bakımından idarece yapılan idari işlemlere dayalı bir değerlendirme yapılması yoluna gidilmektedir. Bkz. CAN, Hacı, "Avrupa Birliği Yargılama Hukukunda Maddî Olayın Tespiti”, Fasikül Hukuk Dergisi, Yıl:5, Sayı:43, 2013 , s.8. ODER/AYANOĞLU, s.119.

TAN, İdare Hukuku, s.1159. D11D. E.1974/7105, K.1974/2261, T.21.11.1974, DD. Sayı:18-19, s.616. 
çıkarımı da beraberinde getirmektedir. Esasen bireylerin yargısal yola başvurması bakımından belirli hukuki durumların tespitinde hukuki menfaatinin bulunması, tespit davalarının bu noktada gerekli olduğunu da göstermektedir. Belirtmek gerekirse, idari yargılama hukukunda yer alan delil tespiti müessesesinin yalnızca maddi olguların saptanmasına yönelmesi karşısında, hukuki durumların tespiti bakımından tespit davalarına gereksinim bulunmaktadır. Nitekim Uyuşmazlık Mahkemesinin içtihatlarında da ortaya konulduğu üzere, kamu hukuku ilişkinin bulunduğu hukuki uyuşmazlıkların çözümünün idari yargı düzeninde olması gerektiği açık olduğundan; adli yargıda var olan tespit davasının çözüm sağlamaktan uzak olduğu ifade edilebilecektir. Bu bağlamda idari yargılama hukukunda tespit davalarının uygulama alanı bakımından kendine özgü özelliklerinin bulunduğundan ve bir gereklilik olarak ortaya çıktığından bahsedilebilecektir. Bunun yanında, tespit davaları neticesinde verilen hükmün idarenin yerine geçerek işlem tesis etme yasağını ihlal ettiği yahut sınırlı sayıda dava türünün bulunması nedeniyle bu davaların idari yargılama hukukunda hiçbir şekilde uygulama alanı bulamayacağı yönündeki genellemelerin bireylerin hak arama hürriyetlerini olumsuz yönde etkilediği belirtilebilir. Oysa tespit davalarının uygulama alanı bulması halinde, hukuki menfaati bulunan bireylerin diğer dava türlerine başvurmaksızın uyuşmazlığı çözebilme imkanın önü açılacak ve bu sayede idari yargının ağır iş yükünün hafifletilmesi de sağlanabilecektir. Bu doğrultuda hukuk devleti ilkesine koşut olarak hak arama hürriyetini sınırlayan bu gibi önsel çıkarımların önüne geçilmesi gerektiğinin altı çizilmelidir.

\section{Kaynakça}

AKYILMAZ, Bahtiyar/SEZGİNER, Murat/KAYA, Cemil, Türk İdari Yargılama Hukuku, Savaş Yayınevi, Ankara, 2018.

AUBY, Jean-Bernard, "Administrative Law in France", Administrative Law of the European Union, Its Member States and the United States (A Comparative Analysis) (ed. SEERDEN, René/STROINK, Fritz), Intersentia, Antwerpen-Groningen, 2002, (ss.59-90).

BİLGEN, Pertev, “İdari Uyuşmazlıklar, Hukuki Nitelikleri, Çözüm Usulleri”, II. Ulusal İdare Hukuku Kongresi Bildiri Özetleri, Danıştay Yayınları, Ankara, 1993, (ss.148-193).

BULL, H. Peter/MEHDE, Veith, Allgemeines Verwaltungsrecht mit Verwaltungslehre, 8. Baskı, C. F. Müller Verlag, Heidelberg, 2009.

CAN, Hacı, “Avrupa Birliği Yargılama Hukukunda Maddî Olayın Tespiti”, Fasikül Hukuk Dergisi, Yıl:5, Sayı:43, 2013, (ss.7-17).

CANDAN, Turgut, “Tespit Davası ve İdari Yargı”, DD. Sayı:72-73, 1989, (ss.3-7).

CANDAN, Turgut, Açıklamalı İdari Yargılama Usulü Kanunu, Maliye ve Hukuk Yayınları, Ankara, 2006.

ÇAĞLAYAN, Ramazan, İdari Yargılama Hukuku, 11.Baskı, Seçkin Yayıncılık, Ankara, 2019.

DEFOORT, Benjamin, La décision administrative, LGDJ, Paris, 2015.

DERDIMAN, R. Cengiz, İdarî Yargının Genel Esasları, Alfa Aktüel Yayıncılık, Bursa, 2014.

DEVELLİĞLU, Ferit, Osmanlıca-Türkçe Ansiklopedik Lugat, Doğuş Matbaası, Ankara, 1962.

DURAN, Lütfi, "İdari İşlem Niteliğinde Vergi Kararlarıyla Vergi Davalarının Çözümü (II)”, Amme İdaresi Dergisi, Cilt:21, Say1:1, 1988, (ss.63-77).

DURSUN, Hasan, "İdari Yargıda Tespit Davasına Yer Verilmesi Bir Zorunluluktur", Terazi Hukuk Dergisi, Say1:24, 2008, (ss.111-135). 
ERDOĞDU, Ahmet, “Tespit Davası”, DD. Sayı:3, 1971, (ss.12-31).

ERDOĞDU, Ahmet, “Almanya'da Tespit ve İptal Dâvalarının Uygulama Biçimi”, DD. Sayı:2, 1971, (ss.59-63).

ERGEN, Cafer, İdari Yargı Davaları, Seçkin Yayıncılık, Ankara, 2008.

ERKUT, Celal, “İ.Y.U.K. Çerçevesinde İdari Dava Türleri ve Bazı Usuli Değişiklikler”, İÜHFM, Cilt:51, Sayı:14, 1985, (ss.221-235).

ERKUT, Celal, “Tespit Davasının İdari Bir Dava Türü Olarak Kabul Edilip Edilemeyeceği Sorununa Uyuşmazlık Mahkemesinin Yaklaşımı”, İHID, Cilt:11, Sayı:1-2, 1990, (ss.6-17).

ERKUT, Celal, “İdari Yargıya Başvuru Haklarının Sınırı ve İdari Davaların Kapsamı”, 2000 Yılında İdari Yargı Sempozyumu, Ankara 11-12 Mayıs 2000, Danıştay Yayınları, Ankara, 2000, (ss.89-96).

ERKUT, Celal/SOYBAY, Selçuk, Anayasa ve İdari Yargılama Hukukuna İlişkin Kanunlar, 5. Baskı, Beta Yayıncilık, İstanbul, 2001.

FIŞ ÜSTÜN, Gül, "Yatırımcıları Koruma Fonu Tarafından Tesis Edilen İdari Para Cezası Bildirim Tutanaklarının Niteliğì, Hacettepe Üniversitesi Hukuk Fakültesi Dergisi, Cilt:1, Sayı:2, 2011, (ss.64-72).

FROMONT, Michel, “Avrupa Topluluğu’na Üye Devletlerde, İdari Kararlar Karşısında Bireylerin Geçici Olarak Korunması Sorunu” (çev. ERKUT, Celal), İHİD, Cilt:7, Sayı:1-3, 1986, (ss.37-71).

GÖZLER, Kemal, İdare Hukuku Cilt-II, 3.Baskı, Ekin Yayınevi, Bursa, 2019.

GÖZÜBÜYÜK, A. Şeref/TAN, Turgut, İdare Hukuku Cilt II: İdari Yargılama Hukuku, 7. Baskı, Turhan Kitabevi, Ankara, 2014.

GÜNDAY, Metin, “İdari Yargının Görev Alanının Anayasal Dayanakları”, Anayasa Yargısı Dergisi, Sayı:14, 1997, (ss.347-358).

GÜRAN, Sait, "Yargı Denetiminin Kapsamı”, İÜHFM (Ord. Sulhi Dönmezer’e Armağan), Cilt 52, Sayı:1-4, 1985, (ss.35-45).

İNCEOĞLU, Sibel, "Hukuk Devletinin İnsan Hakları Avrupa Mahkemesi ve Türk Anayasa Mahkemesi Kararlarında Tezahürü: Karşılaştırmalı Bir Çalışma”, Anayasa Hukuku Dergisi, Cilt:4, Sayı:7, 2015, (ss.85-108).

KALABALIK, Halil, İdari Yargılama Hukuku, 13. Baskı, Seçkin Yayıncılık, Ankara, 2019.

KAPLAN, Gürsel, İdari Yargılama Hukuku, Ekin Yayıncllık, Bursa, 2016.

KARAHANOĞULLARI, Onur, "İdari İşlem Niteliğinde Yargı Kararları ve Vergi Davaları", Prof. Dr. A. Şeref Gözübüyük'e Armağan, Turhan Kitabevi, Ankara, 2005, (ss.199-214).

KARAHANOĞULLARI, Onur, İdarenin Hukukla Kavranması: Yasallık ve İdarî İşlemler, Turhan Kitabevi, Ankara, 2019.

KARAHANOĞULLARI, Onur, İdari Yargı İdarenin Hukuka Zorlanması, Turhan Kitabevi, Ankara, 2019.

KURU, Baki, Tesbit Dâvaları, AÜHF Yayınları, Ankara, 1963.

ODER, Burak/AYANOĞLU, Taner, "Yorum ve Tespit Davaları", İdari Yargının Yeniden Yapılandırılması ve Karşılaştırmalı İdari Yargılama Usulü Danıştay 133. Yıl Sempozyumu, Danıştay Yayınları, Ankara, 2003, (ss.105-140).

ÖZAY, İl Han, Günışığında Yönetim, Filiz Kitabevi, İstanbul, 2004.

ÖZAY, İl Han, Günışı̆̆ında Yönetim II: Yargısal Korunma, On İki Levha Yayıncılık, İstanbul, 2010.

ÖZKOL, Adil, Uyuşmazlık Mahkemesi Kararları Açısından İdari Yargının Görev Alanı, Sevinç Matbaası, Ankara, 1970.

ÖZSOYLU, Kırdar, “İdari Yargıda Tesbit Davalarının Yeri”, DD. Sayı:68-69, 1988, (ss.136-139).

PAZARCI, Ayşe Almıla, İdârî Yargılama Hukuku Açısından Tespit Davasının Uygulanabilirliği, Yayımlanmamış Doktora Tezi, Konya, 2014. 
PRÉVÉDOUROU, Eugénie, Les recours administratifs obligatoires étude comparée des droits Allemand et Français, LGDJ, Paris, 1996.

SCHENKE, Wolf-Rüdiger, Verwaltungsprozessrecht, 12.Bask1, C. F. Müller Verlag, Heidelberg, 2009.

SUNAY, Süheyla Şenlen, İdari Yargılama Usulüne Hakim Olan İlkeler Karşısında İsbat ve Delil Hususları, Kazancı Yayınları, İstanbul, 1997.

TAN, Turgut, "Sinav Notları ve Yargisal Denetim”, DD. Sayı:18, 1975, (ss.187-192).

TAN, Turgut, İdare Hukuku, 7. Bask1, Turhan Kitabevi, Ankara, 2018.

TANRIVERDİ, Ayşe Almıla, "Danıştay Beşinci Dairesinin 03.02.1988 Tarih, 1987/2333 E. 1988/408 K. Sayılı Kararı Uyarınca Danıştay’ın Tespit Davasına Bakışı”, 5.İdare Hukuku Buluşması "Danıştay Kararı İncelemeleri” 4-6 Mayıs 2018, Filiz Kitabevi, İstanbul, 2019, (ss.107-116).

ULUSOY, Ali D., İdari Yargılama Hukuku, Yetkin Yayıncılık, Ankara, 2020.

YASİN, Melikşah, İdari Yargılama Usulünde İspat, On İki Levha Yayıncılık, İstanbul, 2015.

YAŞAR, H. Nuri, İdari Yargı Kararlarının Etkinleştirilmesi Arayışında İdari Yargı İdari Yargıç Yargısal Emir, On İki Levha Yayıncılık, İstanbul, 2013.

YILDIRIM, Turan, "Yargı Kararlarının Uygulanmaması Sorunu”, İdari Yargının Yeniden Yapılandırılması ve Karşılaştırmalı İdari Yargılama Usulü Danıştay 133. Yıl Sempozyumu, Danıştay Yayınları, 2001, (ss.153164).

ZABUNOĞLU, Yahya K., İdare Hukuku Cilt-II, Yetkin Yayıncılık, Ankara, 2012.

\section{Yararlanılan Internet Kaynakları}

- http://emsal.danistay.uyap.gov.tr

- http://www.anayasa.gov.tr/icsayfalar/kararlar/kbb.html

- http://www.mevzuat.gov.tr

- http://www.uyusmazlik.gov.tr

- https://www.lexpera.com.tr

- https://emsal.yargitay.gov.tr

- https://www.legifrance.gouv.fr

- https://www.resmigazete.gov.tr

- http://www.kazanci.com 